\title{
The Adolescent's Behaviors during the Presidential Election 2019
}

\author{
Primada Qurrota Ayun ${ }^{1}$, Sri Budi Lestari ${ }^{2}$, Hedi Pudjo Santosa ${ }^{3}$ \\ \{primadaqa.ayu@gmail.com ${ }^{1}$ \} \\ Universitas Diponegoro, Indonesia ${ }^{1,2,3}$
}

\begin{abstract}
The development of technology makes the lives of adolescents integrated with social and digital media. The existence of general elections always fosters new hope. Around 20 million people who are beginner voters have the opportunity to determine the new leader for Indonesia. The enthusiasm of the novice voters is greatly felt because they will use their political rights for the first time in their lives. This research is a qualitative study using a reception analysis approach conducted by in-depth interviews. The results of this study indicate three responses, namely cognitive, affective, and actional responses. The objective of this study leads to the research question, how the adolescent's behaviors were during The Presidential Election in April 2019 after interpreting political messages in the social media. Cognitive responses revealed their knowledge in understanding the news, affective responses showed that the teenagers did a crosscheck of the news before they behave and actional responses took a stance in determining their choices, based on their own decisions, after they saw the news in the mass media, not only social media.
\end{abstract}

Keywords: News Contents, Social Media, Adolescent's Behaviors, The Presidential Election 2019.

\section{Introduction}

The presence of social media is a determination marker of technological and internet developments in the human life. This medium not only transforms real life into virtual but also has become the uniqueness of media-morphosis in many cases; a term that was popularized by Roger Fidller in the early 1990s.

Social media comes as a new media and its technology which remains a part of the previous media existence. Likewise, the presence and implications of new media must be seen from the present implications of the previous media existence.

As stated in the previous research on "Youth Meanings in the Consumption of Digital Media Content", the development of technology makes the lives of adolescents integrated with social and digital media. On one hand, it is answering the curiosity of adolescents. On the other hand, it is a concern for parents in providing digital access to them. Their concern is about the lack of relevant information which does not represent the rule of $5 \mathrm{w}+1 \mathrm{~h}$, it does not contain accuracy, relevance, and completeness in the displayed content.

In Indonesia political information experienced a surge in volume during the presidential election. However, there is a lot of news that is less relevant on social media, where there is hoax news especially during the election campaign period. As it was quoted from liputan6.com, news or hoax information turns as one of the effects of the development in 
cyber civilization. Nearly all people have devices and can access any information from their cellphones. It is also mentioned, as many as 130 million Indonesians are internet users via devices. Unfortunately, literacy culture in Indonesia is the second lowest in the world, "so that the culture of sharing is not extended by reading" [1].

Elections always generate new hope. More or less 20 million people who were beginner voters had the opportunity to determine the new leader in Indonesia in the 2014 election. The enthusiasm of the novice voters was felt greatly because for the first time in their lives, they would use their political rights. The number of beginner voters in Indonesia from election to election continues to grow. Based on the General Election Commission (KPU) database, a number of first-time voters in the 2014 election reached 11 percent of the total 186 million voters. This number increased compared to the two previous elections. In 2004, the number of first-time voters was around 27 million out of 147 million voters (18.4 percent). While in the 2009 Election, there were around 36 million voters out of 171 million voters (This number was increasing compared to the previous two elections). The article that had aired on Kompas.com entitled "Enthusiasm of Young Voters" at the same time informed that youth as first-time voters seemed relatively enthusiastic to take advantage of their experience to participate in determining the future of their nation [2].

The same article stated that the novice voter group is those aged 17-22 years, and for the first time will participate in the election. They are high school students, college students, or young workers. In the database of the Demographic Institute of the Faculty of Economics, University of Indonesia, this group is well educated, familiar with advanced technology, and gained a lot of influence from television and new media [3]. Having a better education level and access to information, this group tends to understand the latest political developments in Indonesia, and they are expected to make decisions rationally. They are literate in politics and technology.

The discussion of this research leads to the question of research, at the time those teenagers interpreted new media content, especially information about the Presidential Election campaign which was widely published in social media, how were their attitudes towards the Presidential Election which took place in April 2019. What were their attitudes towards the presidential election which was in April 2019, after they interpreted the messages in the media?

\section{Research Method}

This research is a qualitative study applying a reception analysis approach. Reception analysis is used to understand the message constructed by the media to the public. The methodology in this analysis refers to the meaning captured by the audience of the message conveyed in the text. There are three main elements in analyzing reception data Jensen \& Jankowski [3], namely; the collection or generation of data centers on the audience side, the analysis of interviewers and other audiences, and interpretation of audience experience of the media. In reception analysis, the meaning of media is negotiated by individuals based on their experience. In other words, media messages are subjectively constructed to individual audiences. The audience applies various social and cultural backgrounds which was previously obtained by reading the text, so that people who have different characteristics will interpret a text differently. The audience is an active creator of meaning in relation to the text. In conducting this analysis, the next form of data search is by in-depth interview. According to 
Kriyantono [4], in-depth interview is a way to collect data or information by face to face with informants in order to obtain complete and in-depth data.

\section{Theoretical Framework}

As we have seen, one of the media functions is a tool used in the transmission of values. Ardianto and Erdinaya [5] explain that the function of value spreading is also called socialization, that individuals adopt group behavior and values. The mass media that represents the image of the community are watched, heard and read. The mass media show us how they act and what they expect. In other words, the media represent us with the role models we observe and hope to emulate them.

Recently, one of media used as sources of information is social media. Social media can be interpreted as a form of interaction between a number of people through sharing information and ideas through the internet to form a virtual community Ahlqvist, Back A, Halonen, 2008, in Liliweri [6]. Social media content is related to several characteristics of social media. Nasrullah [7] explains some of the characteristics of social media, namely:

a) Network

Social media has characteristics as a network. The core network is formed through information networks that occur among these social media users. Indirectly, this network forms a community, then raises new values in society.

b) Information

Information becomes an important entity in social media because cyber media users are creating representations of their identities, producing content, and carrying out communication processes based on information. Moreover, information becomes a kind of commodity in the information society.

c) Files

For cyber media users, the archive becomes a character which explains that information has been stored and can be accessed at any time and through any device.

d) Interaction

Interaction is a form of relationship that occurs in cyber media. It is about how individuals give comments to each other and respond to messages conveyed.

e) Social simulation

In using cyber media, the interactions occurred indeed illustrate even similar to reality. However, the actual interaction that occurs is a simulation. In other words, it is different from the reality.

f) Content by users

In cyber media, content by users is that the content of cyber media is entirely owned and is based on contributions from users or account holders.

g) Spread

Cyber media not only produces content that is produced and consumed by its users, but also processes the distribution and development of its users.

The objective of this study tries to see how the attitudes of adolescents who became novice voters after they tried to interpret the existing message about political information in the media. Simply stated, attitude can be understood as a form of mindset or tendency to act in a certain way based on individual experience. In understanding attitudes, we will usually indirectly deal with elements of beliefs and behavior. Hockenburry \& Hockenburry (2007) in 
Liliweri [6] explains that beliefs represent what we have learned and received through experience, while behavior is an action taken in relation to an object or entity.

Attitude consists of three basic components, three basic components, emotion, belief, and behavior. The emotional component involves a person's feelings so that they form positive, neutral, or negative feelings towards another person or a certain object. The component of belief is related to the level of our trust in certain content related to someone. Finally, the behavioral component is a form of our attitude statement [6]. In addition, Widoyoko [8] also explained several components of attitude, namely: 1) the Cognition Component, in which this component arises based on understanding, trust and belief in the attitude object. In general, it can be said that the cognition component answers the question of what someone knows, understands and believes about the attitude object that the person holds; 2) Affection Component, this component is the part of attitude that arises based on what students feel about the object. This component is used to find out what is felt when facing an object. Feelings of objects can arise due to cognitive factors and certain factors. Thus, the affective component is a feeling that is owned by someone against an object; 3) Conation component, it is a person's tendency to act and behave in certain ways towards an object based on knowledge and feelings towards the object.

Attitude is a form of mindset or tendency to act on something based on one's experience. A person's attitude can be formulated into three forms of response, namely:

a) Cognitive responses, i.e. responses that are shown based on thoughts about object attitude that appears both verbally and non-verbally.

b) Affective responses, i.e. responses that refer to evaluations and feelings both oral and written.

c) Actional responses, namely the direct expression of behavioral intentions that are usually observed in actions [6].

The adolescent in this study is the beginner voters. They are simply defined as those who participate in the election for the first time. If you observe the first-time voters in this political year 2018-2019, then they are the generation born around the late 1990s or early 2000s. They are around the age of 17 to 21 years old in the current political year. It means the novice voters in this political year are people who are classified into $\mathrm{Z}$ generation. $\mathrm{Z}$ generation also has very visual characteristics. It means that lingering with the text is generally not very attractive to them. This should be considered by political parties or pairs of candidates targeting the $\mathrm{Z}$ generation. Besides, to attract novice voters, the political parties and pairs of candidates also create content that is adapted to the media that they commonly use. For example, by creating Instagram, YouTube, or meme content. Novice voters are often influenced by memorable jingles such as those which are often published via radio or television. Beginner voters seem to have started to leave the print media such as newspapers or magazines [9]

\section{Result and Discussion}

The informants in this study are teenagers who are beginner voters and use the internet as a medium in information seeking. A total of 14 teenage informants were selected purposively from a number of high schools in the Banyumanik subdistrict, Semarang. The results of a study revealed the following attitudes:

a) Beginner voters in $Z$ generation have an interesting pattern in consuming media, they set social media as a source of information. The informants admitted that they did not use 
print media as their information source. Whilst television is still the second way after social media. DN Times launched the 2019 Indonesia Millennial Report to photograph behavior patterns, attitudes, and mental pattern among millennial Indonesian. One of them is about millennial behavior in terms of internet consumption and online habits. In particular, their habits in getting the latest information, anticipating the risk of Fear of Missing Out (FOMO). One result shows that television and digital media are by far the most effective media to reach millennial groups [10].

b) Cognitive responses show that attitudes arise based on the informants' understanding, trust and beliefs in obtaining political information. They understood about political information on social media and television media. They even had the ability to distinguish between true and false political information. Based on knowledge, they tried to sort out the information available, and they were able to differentiate between true information and false information.

c) Affective responses indicate that the informants did a cross-check of the information. The media that they often accessed was social media. They access this media every day. Then, the second media is television. The informants did a cross-check of political information obtained on social media, by looking at the mainstream media (television), discussing with friends, and discussing with parents. For the informants, television media is the right media to be used as the main reference for checking information in social media. They believe that the news in the television media has gone through the process of gate keeping so that the news might not be a hoax.

d) Conation response or action in this research are two folds, the first response is related to how the attitude of the novice voters receive information messages on social media. The results were quite interesting, because they stated they were not interested in spreading information that they thought was unclear. As we know that cyber media has the characteristics of not only producing content that is produced and consumed by its users but also carrying out the distribution process. In fact, the novice voters were not interested in spreading this information. The second response was that they elected the president in the 2019 presidential election by deciding their own choices. This was quite interesting, considering that they conducted a crosscheck by discussing with friends and parents. Then, they made their own choices when they chose. Two informants said that their parents suggested choosing a certain president but they still chose their choice.

\section{Conclusion}

The results of this study indicate three responses, namely cognitive, affective, and actional responses. Cognitive responses showed their knowledge in understanding the news, affective responses showed that the teenagers did a crosscheck of the news before they behaved and the actional responses took a stance in determining their choices, based on their own decisions, after they saw not only social media but also the news in the mass media, and they were independent in their choices.

The behavior they took when they voted in the Presidential Election in April 2019 was acknowledged by the informants as a personal decision, without any influence from the news media on television, radio and social media, as well as from both parents and friends, which according to their confession was only used as a reference material. Also found were several informants who claimed to have different choices from their parents. The basis of the election 
for elected presidential candidates, admitted by the informants, refers more to a real track record, in the form of tangible work that they feel benefits both directly and indirectly, as well as strengthened through reporting both on television and social media that they use as reference when the Presidential Election campaign takes place.

\section{References}

[1] S. Sabandar, "Penyebab Orang Indonesia Rentan Percaya Hoax di Medsos Terkuak," Liputan 6, 2017. [Online]. Available: https://www.liputan6.com/regional/read/2828281/penyebab-orangindonesia-rentan-percaya-hoax-di-medsos-terkuak.

[2] Kompas.com, "Antusiasme Pemilih Muda," 2014.

[3] K. B. \& N. W. J. Jensen, A Handbook of Qualitative Methodologies for Mass Communication Research. London \& New York: Routledge, 1993.

[4] K. Rachmat, "Teknik praktis riset komunikasi," Jakarta, PT Kencana Prenada Media Gr., 2006.

[5] E. dan L. K. E. Ardianto, Komunikasi Massa Suatu Pengantar. Bandung: Simbiosa Rekatama Media, 2007.

[6] A. Liliweri, Komunikasi Antar-Personal. Jakarta: Kencana., 2015.

[7] R. Nasrullah, "Media sosial: Perspektif komunikasi, budaya, dan sosioteknologi," Bandung: Simbiosa Rekatama Media, vol. 2016, p. 2017, 2015.

[8] E. P. Widoyoko, "Penilaian hasil pembelajaran di sekolah," Yogyakarta: Pustaka Pelajar, vol. 1, no. 2, p. 8, 2014.

[9] B. Kiwari, "Pemilih Pemula: Siapakah Mereka?," Kumparan, 2018. [Online]. Available: https://kumparan.com/bandungkiwari/pemilih-pemula-siapakah-mereka-27431110790534325.

[10] B. D. Wicaksono, "5 Fakta Perubahan Pola Konsumsi Media Millennial,” IDN Times, 2019. . 